MAKING THE UNIPOLAR MOMENT 



\section{MAKING THE UNIPOLAR MOMENT}

\section{U.S. FOREIGN POLICY AND THE RISE OF THE POST-COLD WAR ORDER}

HAL BRANDS 
Cover design: Scott Levine.

Copyright (C) 2016 by Hal Brands

All rights reserved. Except for brief quotations in a review, this book, or parts thereof, must not be reproduced in any form without permission in writing from the publisher. For information, address Cornell University Press, Sage House, 512 East State Street, Ithaca, New York 14850.

First published 2016 by Cornell University Press

Printed in the United States of America

Library of Congress Cataloging-in-Publication Data

Names: Brands, Hal, 1983- author.

Title: Making the unipolar moment : U.S. foreign policy and the rise of the post-Cold War order / Hal Brands.

Description: Ithaca : Cornell University Press, 2016. Includes bibliographical references and index.

Identifiers: LCCN 2015048539

ISBN 9781501702723 (cloth : alk. paper)

Subjects: LCSH: United States—Foreign relations1977-1981. | United States-Foreign relations1981-1989. | United States-Foreign relations-1989-1993.

Classification: LCC E872 .B73 2016 |

DDC 327.73009/04-dc23

LC record available at http://lccn.loc.gov/2015048539

Cornell University Press strives to use environmentally responsible suppliers and materials to the fullest extent possible in the publishing of its books. Such materials include vegetable-based, low-VOC inks and acid-free papers that are recycled, totally chlorine-free, or partly composed of nonwood fibers. For further information, visit our website at www.cornellpress.cornell.edu.

Cloth printing $\quad \begin{array}{lllllllllll}10 & 9 & 8 & 7 & 6 & 5 & 4 & 3 & 2 & 1\end{array}$ 